\title{
Effects of feeding frequency on common carp (Cyprinuscarpio L.) growth rate
}

\section{S.A. Hama Amin", N.M. Abdulrahman, V.M. Ahmed, P.B. Ibrahim, R.R. Ismail, M.B. Ahmed and N.M. HamaGareeb}

\author{
Animal Science Department, College of Agricultural Sciences, University of Sulaimani, Kurdistan Region, Iraq \\ *corresponding author: sarwar.hamaamin@univsul.edu.iq
}

(Received July 8, 2017; Accepted August 26, 2017)

\begin{abstract}
In present study the effect of feeding frequency on growth performance, food efficiency and survival rate of common carp fingerlings were investigated. Three groups of common carp fingerlings (average weight $22.88 \pm 1 \mathrm{gm}$ ) designed with three feeding frequencies one meal a day (D1), two meals a day (D2) and three meals a day (D3) with three replicates of each treatment. Fish in experimental treatments were fed by $4 \%$ of body weight. Feeding frequencies had significant effect on growth performance $(\mathrm{P}<0.05)$. The final body weight and specific growth rate $(\mathrm{SGR})$ were significantly higher in group D3 $(\mathrm{P}<0.05)$ in this comparison. Similar responses were observed for body weight increased (BWI) and daily growth rate (DGR) and the best BWI and DGR were obtained in D3 group, that showed significantly different to other groups $(\mathrm{P}<0.05)$. The best feed conversion ratio (FCR) was obtained from three daily feeding (D3), however there were no significant different between $\mathrm{D} 2$ and $\mathrm{D} 3(\mathrm{P}>0.05)$. Also feeding frequencies had positive effect on fish survival rate $(\mathrm{P}<0.05)$. The best results in growth performance and survival rate were obtained by feeding threemeals a day (D3).
\end{abstract}

Keywords: Feeding Frequency, Growth Performance, Common Carp Available online at http://www.vetmedmosul.org/ijvs

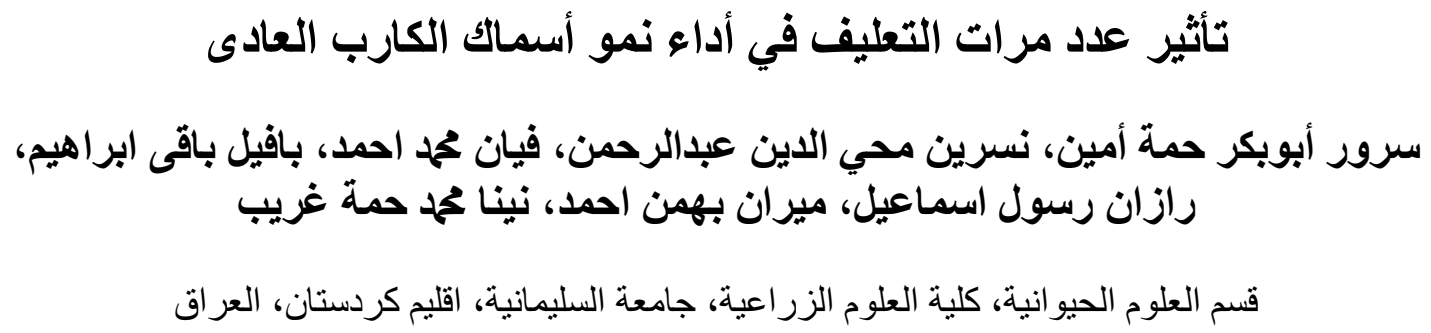

الخلاصة

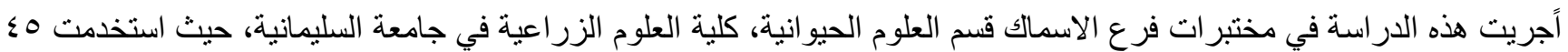

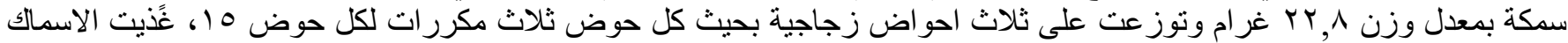

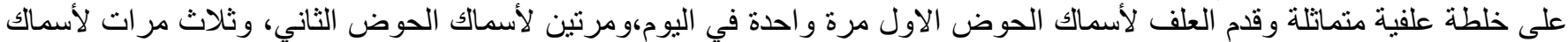

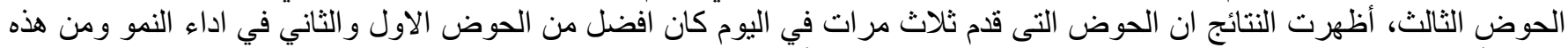

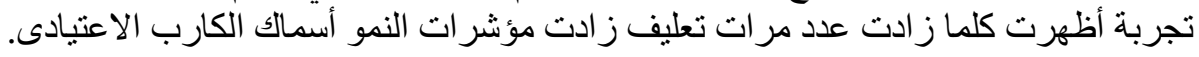

\section{Introduction}

Nutritional requirements of fish for growth, reproduction and normal physiology are similar to the requirements of other domesticated animals. However, fish mainly differ from other animals in their demand for proteins, so usually fed with 25 to $45 \%$ of row proteins are used (1). In this aspect, the efficiency and utilization of proteins are more important in fish. 
Feeding presents the largest part of expenses in intensive and semi-intensive aquaculture, so fish food must be of good quality to assure high utilization, high growth rate, and good health. Fish food is formulated to fulfill the requirements of fish with nutrients and energy. Since the food covers 40 to $60 \%$ of the total expenses in production $(2,3)$.

The aim of this paper was to study the effect of feeding frequency on some growth performance parameters in common carp fingerlings.

\section{Materials and methods}

The experiment was conducted for 65 days using 45 common carp Cyprinus carpio L. which was brought from a local pond located in Qaladzya. Forty five common carp fingerlings with average weight of (D1:22.88gm, D2:21.08gm, D3:21.32gm) were distributed evenly among nine Aquarium. These were static systems cleaned by daily suction, where approximately $10 \%$ of the water in the tanks was replaced daily. We used three feed frequencies which was representing three treatments, treatment number one (D1) consist of one time feeding only which the whole feed was given to the fish, treatment number two (D2) consist of two time feeding daily which the feed was divided in to two parts, treatment number three (D3) consist of three time feeding and the whole feed was divided into three parts.

Table 1 represent the chemical composition of experimental diet (BESLER YEM) SANAYI TICARET LTD. STI.

This experiment was carried out in the fish laboratory of the College of Agricultural Sciences, Department of Animal production, Fisheries Branch, University of Sulaimani in Bakrajo. The number of aquarium in the trial was three representing three treatments. Each aquarium with three partitions, each one represents a different treatment and replicate.

\section{Body weight gain}

Body weight gain $(\mathrm{g} / \mathrm{fish})=$ Mean of weight $(\mathrm{g})$ at the end of the experimental period - weight $(\mathrm{g})$ at the beginning of the experimental period.

\section{Daily weight gain}

Daily weight gain $(D W G)=$ Gain $/$ experimental period .

Specific Growth Rate (SGR) (4)

$$
\mathrm{SGR}=\frac{(\mathrm{Ln} \mathrm{Wf}-\mathrm{Ln} \mathrm{Wi})}{\text { Time (days) }} \times 100
$$

$\mathrm{Wf}=$ final average weight at the end of the experiment, Wi $=$ initial average weight at the beginning of the experiment,
Loge $=$ Natural Logarithm reading, Time $=$ Number of days for the experiment.

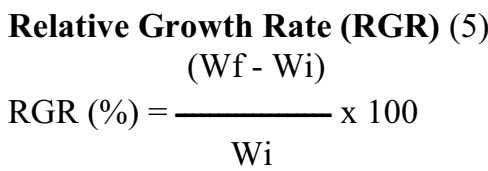

$\mathrm{Wf}=$ final average weight at the end of the experiment, $\mathrm{Wi}$ $=$ initial average weight at the beginning of the experiment.

Feed Conversion Ratio (g) (FCR) (4)

Weight of feed given $(\mathrm{g})$

$\mathrm{FCR}=$

Fish weight gain

Table 1: The chemical composition of experimental diet (BESLER YEM) SANAYI TICARET LTD.STI

\begin{tabular}{lc}
\hline Composition & Ratio $\%$ \\
\hline Dry matter & $(\% \min ) 88$ \\
Crude Protein & $(\% \min -\max ) 28-35 \%$ \\
Crude Fat & $(\% \min -\max ) 2.5-3 \%$ \\
Crude Fiber & $(\% \max ) 18 \%$ \\
Crude Ash & $(\% \max ) 10 \%$ \\
Moisture & $(\% \max ) 10 \%$ \\
Calcium & $(\% \min -\max ) 1.0-3.0 \%$ \\
Phosphorus & $(\% \min ) 1$ \\
NaCl & $2400(\mathrm{Kcal} / \mathrm{Kg} . \mathrm{min})$ \\
Metabolizable Energy & $5000 \mathrm{IU}$ \\
Vitamin A (Per KG) & $700 \mathrm{IU}$ \\
Vitamin D3 (Per KG) & $30 \mathrm{mg}$ \\
Vitamin E (Per KG) & \\
\hline
\end{tabular}

Analysis of variance was conducted using the general linear models (GLM) procedure of XLSTAT. Pro. 7.5 One way CRD (ANOVA). Fisher's L.S.D test's was used to compare between means of the experiment treatments.

\section{Results and discussion}

In the present study, common carp fingerlings had different daily feeding frequencies at three feeding rates. Table 2 shows the growth performance in all different groups at the end of feeding trial. The results clearly showed that increasing the feeding frequency during the time had beneficial effects on the growth parameters on common carp. The maximum of final weight gain was observed in D3 (36.31 \pm 1.81$)$ and the lowest of final weight gain was observed in D1 $(29.94 \pm 3.2)$.

The specific growth rate (SGR) was improved significantly $(P<0.05)$ with increasing the feeding frequency. The growth data clearly indicated that SGR values of groupD3 $(0.65 \pm 0.03)$ was significantly higher 
than those of other groups $(P<0.05)$ and lowest SGR was

observed in D1 (0.28 \pm 0.02$)$.

Table 2: Growth parameters and survival rate of common carp in experimental treatments

\begin{tabular}{lccc}
\hline Treatment & $\mathrm{D} 1$ & $\mathrm{D} 2$ & $\mathrm{D} 3$ \\
\hline Initial weight (gm) & $22.88 \pm 3.4$ & $21.08 \pm 2.1$ & $21.32 \pm 3.4$ \\
Final body weight (gm) & $29.94 \pm 3.2 \mathrm{~b}$ & $31.59 \pm 2.1 \mathrm{~b}$ & $36.31 \pm 1.81 \mathrm{a}$ \\
Body weight Gain (gm) & $7.06 \pm 0.6 \mathrm{c}$ & $10.51 \pm 0.17 \mathrm{~b}$ & $14.99 \pm 1.03 \mathrm{a}$ \\
Daily Growth Rate (DGR) & $0.17 \pm 0.05 \mathrm{c}$ & $0.25 \pm 0.04 \mathrm{~b}$ & $0.39 \pm 0.08 \mathrm{a}$ \\
Specific growth (\%/d) & $0.28 \pm 0.02 \mathrm{c}$ & $0.42 \pm 0.05 \mathrm{~b}$ & $0.65 \pm 0.03 \mathrm{a}$ \\
Relative growth (\%) & $31.71 \pm 2.02 \mathrm{c}$ & $49.94 \pm 1.34 \mathrm{~b}$ & $70.37 \pm 1.22 \mathrm{a}$ \\
Survival rate (\%) & $90.81 \pm 5.71 \mathrm{a}$ & $92.12 \pm 4.28 \mathrm{a}$ & $94.18 \pm 2.18 \mathrm{a}$ \\
\hline
\end{tabular}

*means with different superscripts are significantly different $(\mathrm{P}<0.05)$.

A significant difference was found in daily growth rate (DGR) among common carp received three meals in a day (D3) with other two groups (D1 and D2). The maximum of DGR was observed in D3 $(0.39 \pm 0.08)$ that had significantly different to other groups $(P<0.05)$, followed by D2 $(0.25 \pm 0.04)$ and the lowest of DGR was observed in one meal a day (D1) $(0.17 \pm 0.05)$ that had significantly different to other treatments $(P<0.05)$. The growth parameters were significantly affected by frequency during the time $(\mathrm{P}<0.05)$. In addition, the food conversion efficiency (FCE) by increase feeding frequency was significantly decreased in comparison to those of other groups $(\mathrm{P}<0.05)$ and the lowest FCE was observed in D3 (46 \pm 1.45$)$ followed by D2 $(60 \pm 1.0)$ and had significantly different $(\mathrm{P}<0.05)$ to other groups. The highest FCE was observed in one meal a day $(87 \pm$ $2.65)$ as shown in table (3).

Table 3: Feed Utilization of common carp (Cyprians carpio) in experimental treatments

\begin{tabular}{lccc}
\hline Treatment & $\mathrm{D} 1$ & $\mathrm{D} 2$ & $\mathrm{D} 3$ \\
\hline Feed Conversion Ratio & $1.28 \pm 0.0 \mathrm{c}$ & $1.67 \pm 0.0 \mathrm{~b}$ & $2.19 \pm 0.0 \mathrm{a}$ \\
Feed Conversion efficiency (\%) & $87 \pm 2.65 \mathrm{a}$ & $60 \pm 1.0 \mathrm{~b}$ & $46 \pm 1.45 \mathrm{~b}$ \\
\hline
\end{tabular}

*means with different superscripts are significantly different $(\mathrm{P}<0.05)$.

Survival rate showed no significant differences among treatments and feeding frequency had positive effect on survival rate. The maximum of survival rate obtained on treatment D2 (92.12 \pm 4.28$)$ and D3 (94.18 \pm 2.18$)$ however, these treatments had no significant differences among each other but three meal a day (D3) showed better survival rate than two meal a day (D2). The lowest survival rate observed in one meal a day (D1) $(90.81 \pm 5.71)$ and had significantly different to other treatments $(\mathrm{P}<0.05)$. Goldan and Karplus (6) and Ayd and Kolotoglu (7) they reported feeding frequencies did not significantly affect in survival rates on sea bream (Sparusaurata) and juvenile black sea turbot (Psetta maxima), these results with our founding.

Studies conducted on other fish species have shown that feed consumption and growth generally increased with feeding frequency up to a given limit Bascinar (8). This is in agreement with our findings. In present study treatments of grass carp were fed with three meals per day (D3) were better than two (D2) and one meals per day (D1), to similar research Grayton and Beamish (9), who fed rainbow trout fry, three meals a day were better than one or two, also Andrews and Page (10) reported that the channel catfish Ictalurus punctatus grew more slowly when fed to satiation once per day than when fed 2 or 4 times. This study demonstrated a significant effect of feeding frequency on growth and food conversation ratio in juvenile common carp. The highest weight gain was obtained $(P<0.05)$ by feeding the fish frequently three times a day. It is evident that a higher growth rate depends on both higher and more frequent daily feed supply.

In the study of Dediu et al. (11) found that rainbow trout fed twice a day performed betterthan those fed four times a day, in terms of SGR, DGR FCR and PER. Ganzon-Naret, (12) demonstrated that feeding frequency (once, two, four and sixtimes daily) significantly improved the growth performance and feed utilization of Asiansea bass. The effects of feeding frequency may vary with the different species, size, and age of fish, dietary protein, energy levels and feeding time as well as the environmental factors (13).

Murai et al. (14) indicated the growth performance of carp fed the starch diet was higher than that fed the glucose diet when the feeding frequency was 2 meals day, but the growth performance of carp was not affected by different dietary carbohydrate sources such as glucose, maltose, dextrin and starch when the feeding frequency was 6 meals day. This is in accordance with Furuichi and Yone (15), 
who detected that increasing the feeding frequency could decrease the overloading of metabolic capacity of glucose in carp. Lin et al. (16) indicated one of the major reasons of the lower performances in the 2 meals day feeding than the continuous feeding is the habit sturgeon (eat very small in each meal and eat very slowly). Another reason of the lower performance in the 2 meals day feeding than the continuous feeding may have resulted from the overloading of metabolic capacity in the glucose fed sturgeon and digestibility capacity in the starch fed sturgeon. The overloading led to lower lipogenesis by the lower body lipid content in the 2 meals day- 1 feeding than the continuous feeding sturgeon as shown in Lin et al. (16).

The experiment of Tian et al. (17) showed that under conditions of restricted feeding rate, feeding frequency had a significant effect on weight gain, feed efficiency, protein efficiency ratio and lipid content of the fish. Therefore, based on the results, it suggested that 6 meals day-1 feeding was sufficient for the optimal growth and feed efficiency for grass carp on 35.1-37.5 g.

\section{References}

1. Murai T. Protein nutrition of rainbow trout. Aquaculture. 1992;100:191-207.

2. Meyers SP. Aquafeed formulation and ingredients. In: Chang YK, Wang SS. (eds.) Advances in extrusion technology. Aquaculture / animal feeds and foods. Technomic Publishing Company, Inc. Lancaster, PA.USA. 1999;pp:19-27.

3. Aarseth KA, Sorensen M, Storebakke TN. Effects of red yeast inclusions in diets for salmonids and extrusion temperature on pellet tensile strength: Weibull analysis. Anim Feed Sci Technol. 2006;126:75-91.

4. Hepher B. (1988). Nutrition of pond fishes. Cambridge University press, Cambridge. 1988: pp 27

5. Wannigama DN, Weerakon DEM, Muthukumarana G. Cage culture of S. niloticus in Sri Lanka: Effect of Stocking Density and Dietary Crude Protein levels on growth. International Development Research Center Ottawa, Canada, 1985.
6. Goldan O, Popper D. Karplus I. Management of size variation in juvenile gilthead sea bream (Sparusaurata). I: Particle size and frequency of feeding dry and live food. Aquaculture 1997;152:181190.

7. Aydin I, Kucuk E, Sahin T, Kolotoglu L. The effect of feeding frequency and feeding rate on growth performance of juvenile Black Sea Turbot, Psetta maxima (Linneaus, 1758) J Fishscicom. 2011;5:35-42.

8. Bascinar N, Cakmak E, Cavdar Y, Aksungur N. The effect of feeding frequency on growth performance and feed conversion rate of Black sea trout (SalmotruttalabraxPallas, 1811). Tur J Fisheries Aquatic Sci. 2007; 7:13-17.

9. Grayton BD, Beamish FWH. Effects of feeding frequency on food intake, growth and body composition of rainbow trout (Salmogairdneri). Aquacul. 1977;11:159-172.

10. Andrews JW. Pages JW. The effects of frequency of feeding on culture of catfish. Trans. r Am. Fish. Soc. 1975;104:317-321.

11. Dediu 1, Cristea N, Mocanu M, Dicu D, Docan A, Grecu I. The effect of feeding frequency on growth performance of rainbow trout fingerlings reared in recirculating system. Aquaculture, Aquarium, Conservation and Legislation International. $J$ Bioflux Soc. 2011;4(2):141-145

12. Ganzon-Naret ES. Effects of feeding frequency on growth, survival rate and body composition in sea bass (Latescalcarifer) juveniles fed a commercial diet under laboratory condition. Ani Biol Ani Husb Interna J Bioflux Soc. 2013;5(2):175-182.

13. Mihelakakis A, Yoshimatsu T, Tsolkas C. Effects of feeding frequency on growth, feed efficiency and body composition in young common pandora. Aquacul Intern. 2001;9:197-204.

14. Murai T, Akiyama T, Nose T. Effects of glucose chain length of various carbohydrates and frequency of feeding on their utilization by fingerling carp. Bull Jap Sot Sci Fish. 1983;49:1607-1611.

15. Furuichi M, Yone Y. Change in activities of hepatic enzymes related to carbohydrate metabolism of fishes in glucose and insulin glucose tolerance tests. Bull Jap Soc Sci. Fish. 1982;48:463-466.

16. Lin JH, Cui Y,. Hung SSO, Shiau SY. Effect of feeding strategy and carbohydratesource oncarbohydrate utilization by white sturgeon (Acipensertransmontanus) and hybrid tilapia (Oreochromisniloticus $\times$ O. aureus). Aquacul. 1997; 148:201-211.

17. Tian LX, Liu YJ, Hung SS, Deng DF, Yang HJ, Niu J, Liang GY. Effect of Feeding Strategy and Carbohydrate Source on Carbohydrate Utilization by Grass Carp (Ctenopharyngodonidella). Amer J Agricul Biolog Sci. 2010;5(2):135-142. 